\title{
Öğrencilerin Öğretim Üyelerine Yönelik Memnuniyetlerinin İncelenmesi
}

\section{Analysis Satisfaction Level of the Students with Instructors}

\author{
Ayşegül KARATAŞ ${ }^{1}$ \\ Halil ŞİMDİ ${ }^{2}$ \\ Hakan TUNAHAN ${ }^{3}$
}

• Geliş Tarihi: 03.03.2019 • Kabul Tarihi: 10.04.2019• Yayın Tarihi: 01.09.2019

\section{$\ddot{O} z$}

Yükseköğretimde, alınan derslerin ve derslerin öğretim elemanlarının dersi alan öğrenciler tarafından değerlendirilmesi her geçen gün yaygınlığı artan bir uygulamadır. Yazında, değerlendirilen anketlerin öğretim elemanının performansı dışında bazı faktörler etkisinde sapmalı sonuçlar verebileceğine dair tartışmalar bulunmaktadır. Bu faktörler arasında alınan dersle ilişkili değişkenler, öğretim elemanı ile ilgili öğretim performansı dışındaki değişkenler ve sınıf farklılıklarının olduğu öne sürülmektedir.

$\mathrm{Bu}$ araştırmanın amacı sınıf farklılıklarının öğretim elemanlarına yönelik memnuniyeti belirleyen faktörler üzerinde bir etkisi olup olmadığını tartışmaktır. Araştırmanın veri setini, Sakarya Üniversitesi Uluslararası Ticaret Bölümü'nde 2014 yılından 2019 yılına kadarki tüm dönemlerde ders alan öğrencilerin her dönem derslerin öğretim üyelerini değerlendirdiği anketler oluşturmaktadır ve böylece çalışmada yazındakinin aksine boylamsal veri kullanılmaktadır. Öncelikle bir yıl arayla bölüme kaydolan ve birinci dönemden yedinci döneme kadar alınan tüm dersleri değerlendirilen iki ayrı sınıfın verileri incelenerek açıklayıcı faktörler karşılaştırılmaktadır. İkinci olarak da farklı sınıf düzeylerindeki öğrencilerin öğretim üyelerine yönelik memnuniyetlerini belirleyen faktörlerin farklılaşıp farklılaşmadığı araştırılmıştır. Analiz sonucunda bu iki sınıfın öğretim üyelerine yönelik memnuniyetini belirleyen faktörler ve bu faktörlerin yükleri arasında önemli farklılıklara rastlanmamıştır. Ancak tespit edilen faktörlerde ise farklı sınıflarda bulunan öğrenciler arasında önemli farklılıklar olduğu gözlemlenmiştir. Bu bulgudan yola çıkarak birinci sınıftan dördüncü sınıfa kadar devam eden öğrenim süresince öğrencilerin beklentilerinin farklılaştığı görülmektedir.

Anahtar sözcükler: yükseköğretimde ögretim üyesine yönelik memnuniyet, ders değerlendirme anketleri, sınıf farkl11ıkları, öğretim performansı.

\section{Atıf:}

Karataş, A., Şimdi, H., \& Tunahan, Ha.(2019). Öğrencilerin öğretim üyelerine yönelik memnuniyetlerinin incelenmesi. Pamukkale Üniversitesi Eğitim Fakültesi Dergisi, 47, 225-244.doi: 10.9779/pauefd.534868

\footnotetext{
${ }^{1}$ Arş. Gör., Sakarya Üniversitesi, İşletme Fakültesi, Uluslararası Ticaret Bölümü, ORCID: 0000-0002-8587-5994, karatas@sakarya.edu.tr.

${ }^{2}$ Arş. Gör., Sakarya Üniversitesi, İşletme Fakültesi, Uluslararası Ticaret Bölümü, ORCID: 0000-0002-9395-0667, hsimdi@sakarya.edu.tr.

${ }^{3}$ Doç. Dr., Sakarya Üniversitesi, İşletme Fakültesi, Uluslararası Ticaret Bölümü, ORCID:0000-0002-9556-214X, htunahan@sakarya.edu.tr.
} 


\begin{abstract}
In higher education, the evaluation of the instructors by students has become a common practice over the years. These evaluations which are generally based on questionnaire have been accepted as inputs in decisions regarding quality improvement in education. On the other hand, some researchers suggest that questionnaires may produce deviant results by the effect of some factors except the performance of the instructor. Among these factors, it is claimed that there are variables related to the course taken, variables related to the instructor other than teaching performance and class differences.

The primary objective of the paper is to discuss whether class differences have an impact on the differences have an impact on the factors determining the satisfaction with instructors. The data set of the study consists of questionnaires in which all students at International Trade Department of Sakarya University Business School taking courses in all semesters between 2014 -2018 evaluate the lecturers of each semester and thus longitudinal data is used in the study. There are two different classes and who attended to all the courses of the program one year apart. According to results significant differences on the factors determined between the students in different classes were observed.

Keywords: satisfaction with instructor in higher education, student evaluation of teaching (set), class differences, teaching performance.
\end{abstract}

\title{
Cited:
}

Karataş, A., Şimdi, H., \& Tunahan, Ha.(2019). Analysis satisfaction level of the students with instructors. Pamukkale Üniversitesi Eğitim Fakültesi Dergisi, 47, 225-244. doi: 10.9779/pauefd.534868 


\section{Giriş}

Üniversite öğrencilerinin, dersin öğretim üyesini performansına göre değerlendirmeleri, dünya genelinde okullarda yaygın olarak uygulanan, öğretimin ve öğretim elamanlarının gelişimini amaçlayan izlemsel değerlendirmelerdir (Aigner ve Thum, 1986; Hobson ve Talbot, 2001; Zabaleta, 2007). Bu değerlendirmeler, birçok üniversitede öğretimin etkinliğini ölçmek için kullanılan etkili ve kimi zaman tek olan ölçme unsuru olarak görülmektedir (Kwan, 1999).

Öğretici merkezli ve otoriter bir yapısı olan geleneksel eğitim düzeni, 21. yüzyıldaki devrimsel gelişmelerden etkilenerek öğrencileri giderek önemseyen ve fikirlerine değer veren bir sistem olarak görülmektedir (Dunrong ve Fan, 2009). Nitekim ABD'deki yükseköğrenim kurumlarının 1973'te sadece \%28'i öğrenci değerlendirmelerini kullanırken bu oran 1984'te \%68'e ve 1993'te ise \%86'ya ulaşmıştır (Seldin, 1993). Diğer taraftan Esen ve Esen (2015) Türkiye'de öğretim üyelerinin performans değerlendirmesine yönelik olarak yapılan çalışmaların yaygın olmadığını vurgulamaktadırlar. Değerlendirmeleri önemli olarak gören Wachtel (1998) öğrenci değerlendirmelerinin dersin öğretim üyesinin kendisini geliştirmesine yardımc1 olabileceğini ve muhtemelen öğrenimin kalitesini yükselteceğini aktarmaktadır. Ayrıca yapılan anketler, öğretim etkinliğinin ölçülmesine ve yönetimin buna bağlı olarak kararlar almasına, öğrenciler için ders ve dersin öğretim üyesinin seçimi döneminde bilgi sağlamasına ve bu bağlamda müfredatın gözden geçirilmesine yardımcı olmaktadır (Marsh, 1987). Kember ve Wong'a (2000) göre ise değerlendirme anketleri bir hüküm aracı yerine bir geri bildirim kaynağı olarak görülürse öğretimde ve öğrencilerin öğrenme motivasyonlarında gelişmeler kaydedilmesi daha olasıdır. Her hâlükârda, bu tip değerlendirmelerin öğretimin iyileştirilmesine katkıda bulunacağı yazında öngörülmektedir.

Öğrenci değerlendirmelerine verilen önemin artışı, bu değerlendirmelerde kullanılan ölçeklerin geçerliliğinin ve güvenilirliğinin sorgulanmasına neden olmaktadır. Bu konuda Clayson (2018), öğrenci değerlendirme anketlerinin güvenilir olması adına çalışmaların, sınıfları karşılaştırarak yapılmasının daha doğru olacağını belirtmektedir. Nitekim Neath (1996), sınıf büyüklüğü ile öğrenci değerlendirmesi arasında negatif yönlü bir ilişki olduğunu aktarmakta ve küçük sınıfların değerlendirmelerinin daha yüksek puanlama eğiliminde olduğunu belirtmektedir. Sinıfsal farklılıklara ek olarak öğrenciler tarafından yapılan bu değerlendirmelerin dersle ve öğretim üyesinin kişisel özellikleriyle ilgili faktörlerden de etkilendiği öne sürülmektedir. Ancak, Greenwald (1997) bu tip sapmalara rağmen, bu uygulamaları değerli ve geçerli bulmaktadır.

Heine ve Maddox (2009), öğrenci değerlendirme anketlerine yönelik yapılan değerlendirmeler vesilesiyle iki temel algının ölçüldüğünü ileri sürmektedir. $\mathrm{Bu}$ algılar, öğrencilerin dersin öğretim üyesinin sınıftaki performansına yönelik algı ile öğretim etkinliği ve kalitesine yönelik algıdır. Bu araştırmada bir aşama daha ileri gidilerek bu algıların öğretim üyelerine yönelik memnuniyeti belirlemedeki rolü tartışılmaktadır. Öğrencilerin öğretimin nihai tüketicisi ve doğrudan bu hizmetin faydalanıcıları oldukları (Hajdin ve Pazur, 2012) göz önüne bulundurulduğunda anket sonuçlarını hizmet sağlayıcısına yönelik yapılan bir memnuniyet araştırması olarak ele almak mümkündür. Dolayısıyla ders değerlendirme anketleri üzerinden öğretim üyelerine yönelik memnuniyeti etkileyen faktörler değerlendirilmektedir. Bu 
değerlendirmeler Sakarya Üniversitesi İşletme Fakültesi Uluslararası Ticaret bölümünde 20142019 yılları arasında uygulanan öğrenci değerlendirme anketleri incelenerek yapılmaktadır.

Yazında çeşitli üniversitelerde uygulanan benzer anketlerle yapılan çok sayıda araştırma olmasına rağmen bu çalışmaların çoğunda yatay kesit verisi kullanıldığı görülmektedir. Bu çalışmada ise sistematik şekilde yıllar itibariyle uygulanan değerlendirme anketleri analiz edilmektedir. Dolayısıyla kullanılan verilerin boylamsal olması araştırmaya özgün bir değer katmaktadır. Araştırma verisinde birinci sınıftan dördüncü sınıfa kadar aldıkları tüm dersleri değerlendiren iki farklı sınıfın verisi bulunmaktadır. Bu iki farklı sınıf, aynı öğretim üyelerinden alınan aynı dersleri dört yıl boyunca değerlendirmişlerdir. Ders değerlendirme konusunda, ait olunan sınıfın etkisini görebilmek ve uygulanan anketin dışsal geçerliliğin etkili şekilde ölçümleyebilmek adına bu iki farklı sınıfın analiz sonuçlarını karşılaştırmak oldukça önemli çıktılar elde edilmesine olanak sağlayabilecektir. Ayrıca dersin öğretim üyesinin performansının değerlendirilmesinde farklı sınıflardaki (birinci sınıflar, ikinci sınıflar vb.) öğrencilerin değerlendirme kriterlerinin farklılaşıp farklılaşmadığı araştırma kapsamında irdelenmektedir.

Çalışmanın ikinci bölümünde yazın incelemesi alt başlıklarla beraber ele alınacaktır. Üçüncü bölümde ise bu çalışmanın yöntemi aktarılacak olup sonraki başlıkta araştırmanın analizi ve bulguları üzerinde durulacaktır. Son olarak çalışmanın sonuçları aktarılarak öneriler belirtilecektir.

\section{Yazın İncelemesi}

Çalışmanın yazını üç alt başlıkta incelenmektedir. Öncelikle öğrenciler tarafından yapılan dersin öğretim üyesini değerlendiren anketlerin geçerliliği ve güvenilirliği üzerinde durulmaktadır. İkinci kısımda, öğrencilerin öğretim üyesini değerlendirmelerinde etkili olan faktörleri inceleyen çalışmalar ele alınmaktadır. Üçüncü kısımda ise Türkiye'de bu konuda yapılan çalışmalar incelenmektedir.

\section{Öğrenci Değerlendirme Anketlerinin Geçerliliği ve Güvenilirliği}

Öğretim etkinliğinin tanımlanması ve ölçülmesi yükseköğretimde alınacak birçok karar üzerinde etkili olabilmektedir. Bu anlamda uygulanan bu anketlerin geçerliliği ve güvenilirliği konusunda çok sayıda araştırma yapıldığı görülmektedir.

Dışsal geçerliliğin ölçümlenmesi açısından bazı araştırmacılar öğrenme düzeyi ve öğretim açısından sağlanan fayda ile ders değerlendirme anketleri sonuçlarının arasındaki ilişkiyi sınamışlardır. Cohen (1981) ve Marsh (1984) anket puanlamaları ile öğrenme düzeyleri arasında bir ilişki olup olmadığını sorgulamakta ve pozitif yönlü bir ilişki olduğunu ileri sürmektedirler. Bu tespiti Alemoni ve Hexner (1980) ile McKeachie (1990) de desteklemekte ve öğrencilerin kendilerine en çok öğretim açısından faydalı olan hocaları için en yüksek puanı verdiğini belirtmektedirler. Bunlara karşın Pounder (2007) ise kimi zaman öğrenci değerlendirme anketlerinin sonuçlarının öğretim performansıyla öğrenci başarısı arasındaki ilişkiyi ortaya koyamadığını ileri sürmektedir.

Yapılan değerlendirme anketlerinin sonuçlarının gerçeği ne kadar yansıttı̆̆ ne derece doğru şekilde uygulandığ 1 ile de ilişkilidir. Anket sonuçlarının öğretimin iyileştirilmesi adına kullanılması öğrencilerin vereceği puanlamalara daha nesnel yaklaşmasını 
sağlayacak ve sapmaları ortadan kalkmasına yardımcı olacaktır (Chen ve Hoshower, 2003). Bu konuda Ahmadi vd. (2001) işletme öğrencilerine yönelik olarak yaptığı çalışmada öğrencilerin çoğunun değerlendirmelerde sorulara nesnel ve ciddi yanıtlar verdiğini vurgulamaktadırlar. Bu bulgu, anket sonuçlarının geçerliliğini destekler niteliktedir.

Bu bulgulardan yola çıkarak ders değerlendirme anketlerinin yükseköğretimde öğrenimin iyileştirilmesi konusunda kullanılabileceği sonucuna varılmaktadır. Ancak, bu anketlerin hangi örneklemlerde uygulandığı ve bu bağlamda anket sonuçlarının genelleştirilebilirliği konusu oldukça önem arz eden konular olarak değerlendirilmektedir. Öğrenci değerlendirme anketlerinin ne derece geçerli ve genelleştirilebilir olduğu konusunda, değerlendirilmesi gereken üç ana değişken grubu bulunmaktadır: öğretim elemanıyla ilişkili faktörler, sınıfla ilgili faktörler ve dersle ilgili faktörler.

Öğretim elemanları ile ilişkili faktörlerle başlamak gerekirse, Kaschak (1978) ile Sinclair ve Kunda (2000) öğrenci değerlendirmelerinde öğretim üyelerinin cinsiyetine göre sapmaların olabileceğini aktarmaktadırlar. Benzer şekilde Radmacher ve Martin (2001) de örneklemlerindeki öğretim elemanlarının ağırlıklı olarak kadın olması nedeniyle çalışmalarının genelleştirilmesinde sakınca olabileceğini belirtmektedirler. Ders değerlendirmelerinde sapmalara neden olabilecek, öğretim elemanı ile ilgili bir diğer faktörün "karizma" olduğu belirtilmektedir (Shevlin vd., 2000). Zabaleta (2007) ise, çalışma deneyimi az olan öğretim elemanlarının değerlendirilme puanlarının tecrübeli öğretim elemanlarına göre daha yüksek olduğunu vurgulamaktadır. Bu bulgu oldukça akıl karıştırıcı olmakla beraber öğretme istekliliğinin yıllar itibariyle azalması ya da öğretim elemanlarının yaş1 ile öğrencilerin yaş1 arasındaki farkın değerlendirmelerde etkili olabileceği nedenleriyle bu durumun açılanması mümkündür. Neticede öğretim elemanının yaşının ya da tecrübesinin de bu değerlendirmelerde etkili olduğunu öne sürmek yazından hareketle yanlış olmayacaktır.

Ders değerlendirmelerinde geçerlilik ve genellenebilirlik konusunda dikkat edilmesi gereken bir diğer konu dersle ilişkili faktörlerdir. Kember ve Wong (2000) ve Wachtel (1998) ders değerlendirme anket sonuçlarının dersin zorluk derecesine ve akademik disipline bağlı olarak farklılaşabileceğini vurgulamaktadırlar.

Ders değerlendirmelerinde sapmalara neden olabilecek bir diğer değişken grubu sınıfla ilgili olan değişkenler setidir. Radmacher ve Martin (2001), küçük bir sınıf üzerinde uygulanan anketlerin sonuçlarının büyük sınıflar için geçerli olamayabileceğini ifade etmektedirler. Bu yaklaşımın aksine, Cashin (1995) sınıf büyüklügünün öğrenci değerlendirmelerinde sapmalı sonuçlara neden olmayacağını ifade etmektedir. Öğrencilerin dersin öğretim üyesini değerlendirirken dersi aldıkları sınıf ile ilgili faktörlerin bu değerlendirmeleri etkileyip etkilemediğini araştırmak bu çalışmanın da amaçlarından biri olduğu için bu konu Bölüm 2.2'de daha detaylı şekilde incelenmektedir.

\section{Öğretim Üyesinin Performansının Değerlendirilmesinde Sınıfsal Farklııklar}

Üniversite öğrencisi, her ne kadar kendi amacı olan bağımsız bir birey olsa da kendini kısıtlayan, rehberlik eden ve benliğinin sürdürülebilmesine katkı sağlayan bir grubun üyesidir. İlgili grup ise çoğu zaman bu öğrenci için üniversitedeki mensubu olduğu sinıftır (Forsyth, 2014). Yükseköğrenim gören öğrencilere ilişkin Monks ve Schmidt (2010) tarafindan yapılan 
çalışmada bireyin ait olduğu sınıfın büyüklüğü ve sınıfla olan duygusal bağları öğrencinin başarısını, öğrenme kapasitesini ve hayata ilişkin bakışını etkilediğini öne sürmektedirler. Sınıfın büyüklüğüne dair olarak yazında yapılmış olan çalışmaların çoğu ilkokul ve lise ölçeğinde olsa da (Hanushek vd., 2003; Hoxby, 2001) sınıfın fiziki koşullarını ve akran değerlendirmesini dikkate alan üniversite öğrencilerini inceleyen çalışmalar da (Arcidiaccono ve Nicholson, 2005; Martins ve Walker, 2006; Siegfried ve Kennedy, 1995) bulunmaktadır.

Sınıf büyüklüğünün öğrencilerin aldığı eğitimin niteliği ve etkinliği üzerinde etkili olduğu konusunda pek çok öğretim elemanı hemfikirdir (Pedder, 2006). Ancak bu görüşün aksini savunanların da bulunduğu görülmektedir. Örneğin, Martins ve Walker (2006) çalışmalarında üniversite öğrencilerinin başarıları üzerinde sınıf büyüklüğünün önemli olmadığını aktarmaktadırlar. Sınıf büyüklüğüne ilişkin yapılan çalışmaların çoğunluğu öğrencilerin başarılarına yönelik olarak ele alınmaktadır. Bununla birlikte Thng (2017) sınıf büyüklüğü ile öğrenci davranışlarındaki değişimi ve sınıf büyüklüğünün öğrenci-öğretmen etkileşimi üzerindeki etkilerini incelemektedir. Sınıftaki mevcudun yüksek olması öğretmen ile öğrenci arasındaki etkileşim seviyesini düşürdüğünü aktaran Thng (2017), küçük sınıfta bulunmanın öğrenci davranışlarına olumlu olarak yansıdığını belirtmektedir.

Davranışsal açıdan sınıfların iç dinamiklerinin dikkate alınarak öğrenci değerlendirmelerinin irdelenmesi daha doğru sonuçlar verebilmektedir. Bireylerin günlük aktivitelerinin gruplarla beraber yapıldığı düşünülürse öğrencilerin bulundukları sınıftaki duygusal bağların ve grup psikolojisinin, yapılan değerlendirmeleri etkilemesi mümkün olabilmektedir. Bu bağlamda Forsyth (2014) gruplardaki bireylerin kendi aralarındaki etkileşimden dolayı düşüncelerinin, duygularının ve kararlarının birbirlerinden etkilendiğini belirtmektedir. Nitekim Kulik (2001) öğretim üyesi değerlendirmelerinde sinıftaki diğer öğrencilerin yorumlarının öğrencilerin yaptıkları değerlendirme anketleri üzerinde etkili olduğunu vurgulamaktadır. Öğrenciler yaptıkları değerlendirmelerde ait oldukları sınıftaki duygusal bağlarından ve sınıfin fiziksel büyüklüğünden etkilenmekte ve buna bağlı olarak dersin öğretim üyesini değerlendirmektedirler. Clayson (2018) konuya sınıfsal açıdan yaklaşarak, öğretime yönelik olarak yapılan öğrenci değerlendirmelerinin güvenilirliğinin, sınıflar arası olacak şekilde ele alındığında dersin hocasından ziyade öğrenciler hakkında bilgiler sağladığı için daha yüksek güvenilirlik seviyesine ulaşacağını belirtmektedir. Marsh (1984) da bu anlamda, rastgele sınıflara atanan öğrencilerin oluşturduğu sınıflarda aynı dersin, aynı kaynaklarla uygulanmasının ardından yapılacak anket değerlendirmelerinin daha geçerli olabileceğini savunmaktadır.

Sonuç olarak yazında, ağırlıklı olarak sınıfsal farklılıkların ders değerlendirme anketleri sonuçları üzerinde sapmalara neden olabileceği belirtilmekte, bu sapmaların önüne geçilmesi için çözüm önerileri öne sürülmektedir.

\section{Türkiye'de Yapılan Çalışmalar}

Öğrenci değerlendirme anketlerine yönelik olarak Türkiye'de yükseköğrenimde yapılan çalışmalar özellikle son dönemlerde niceliksel açıdan artı̧̧ göstermektedir.

Yapılan araştırmaların pek çoğunun keşifsel nitelik taşıdığı, öğretim üyelerinin değerlendirmelerinde öğrencilerin yanıtlarının basit ortalamalarının değerlendirildiği ya da 
faktör analizi ile boyutların belirlenmeye çalışıldığı görülmektedir (Pamuk, 2005; Patır, 2009). Örneğin, Devebakan vd. (2003) yaptıkları çalışmada Dokuz Eylül Üniversitesi Sağlık Bilimleri Enstitüsü öğrencilerinin değerlendirme anketlerini tanımlayıcı istatistiki bilgilerle yorumlamaktadırlar. Buna göre öğrenciler lisansüstü eğitimde dersin öğretim elemanlarının bilgi ve beceri açısından yeterli görmekteyken, derslerin içeriğinin yeterli olmadıklarını belirtmektedirler. Benzer şekilde Tonbul (2008) da Ege Üniversitesi'nin çeşitli fakültelerinde okuyan öğrencilere uyguladığı anketi frekans analizi ile analiz etmektedir. Ancak Başkır vd.'nin (2015) mühendislik fakültesinde yaptığı araştırmalarında, bulanık mantık yöntemini kullanmakta ve bu yaklaşımının klasik ortalama yöntemine göre daha duyarlı olduğunu belirtmektedirler. Buna ek olarak yazında faktör analizini kullanan Açan ve Saydan (2009), Kafkas Üniversitesi İktisadi ve İdari Bilimler Fakültesi öğrencilerinin öğretim elemanlarından beklentilerine yönelik olarak yedi boyut ve yirmi sekiz ifadeden oluşan bir yapiya ulaşmaktadırlar. Çalışmanın sonuçları irdelendiğinde açıklanan varyansın \%55,87 olduğu görülmektedir. Ayrıca Kim vd.'nin (2016) bir işletme fakültesindeki öğrencilerin öğretim elemanlarının genel performansını değerlendirdikleri çalışmalarında ise üç faktör boyutunda yirmi dokuz ifadenin toplam varyansın \%71'ini açıkladığını ifade etmektedirler.

Türkiye yazınında, öğrenci değerlendirmelerinin hangi faktörlerden etkilendiğinin araştırıldığı çalışmalara da rastlanmaktadır. Bu faktörlerden ilki, öğrencilerin devam ettiği bölümdür. Örneğin, Noyan ve Yıldız (2006) Yıldız Teknik Üniversitesi 2002-2003 öğretim yılında toplanan verilerle yaptıkları çalışmalarında, öğretim elamanlarının performanslarının öğrencilerin devam ettiği bölüme göre farklılaştığını göstermektedirler. Bu bulguyu destekleyen bir diğer araştırma da, Başkır vd. (2017) tarafından yapılan Bartın Üniversitesi’nde yüz on öğretim üyesinin değerlendirildiği çalışmadır. Bu araştırmada kümeleme analizi yapılmakta ve değerlendirme sonuçlarının bölümden bölüme değiştiği gözlemlenmektedir.

Türkiye'deki yazında öğretim üyelerinin değerlendirilmesini etkileyen bir diğer faktör olarak öğretim elemanlarının cinsiyetinin de ele alındığı görülmektedir. Örneğin, Yurtkoru ve Sipahi (2003) öğretim elamanlarının cinsiyetinin etkisini ölçtükleri araştırmalarında, Marmara Üniversitesi İngilizce İşletme bölümü öğrencilerine iki dönem süresince uygulanan anketleri analiz ederek, öğrencilerin değerlendirdiği derslerde, öğretim elemanlarının cinsiyetinin etkili bir faktör olmadığı sonucuna ulaşmaktadırlar.

Bunlarla birlikte, Türkiye'de yapılan çalışmalarda sınıfsal farklılıkların öğretim elemanlarının değerlendirilmesi üzerindeki etkisi konusunda yapılan bir araştırmaya rastlanılmamıştır. Üniversite öğrencileri tarafından yapılan değerlendirme anketlerine istinaden Tonbul (2008) derslerin öğretim elemanlarının yapılan geribildirimleri önemsediklerini gösteren davranışlar sergilemelerinin daha nesnel sonuçlar ortaya koyacağını belirtmekte ve buna ek olarak sınıfların fiziksel özelliklerinin iyileştirilmesinin dersin öğretim üyesinin performansını artıracağını ifade etmektedir.

Yapılan bu çalışmada Türkiye'de yapılmış olan diğer çalışmalardan farklı olarak sınıfsal seviyelerin öğretim üyesi değerlendirmelerinde etkili olan faktörler üzerinde etkili olup olmadığı irdelenmektedir. Ayrıca, yine yazındaki çoğu çalışmadan farklı olarak yatay kesit değil; yedi dönemlik bir zaman dilimi süresince elde edilen boylamsal veri kullanılmaktadır. Bu veriler sayesinde yedi öğrenim dönemindeki tüm derslerin öğretim elemanlarının 
değerlendirildiği iki farklı sınıfın verilerinin ayrı ayrı analiz edilerek sonuçlarının karşılaştırılması mümkün olmakta, dışsal geçerlilik de bu vesile ile ölçümlenmektedir.

\section{Yöntem}

Araştırmanın evrenini Sakarya Üniversitesi (SAÜ) İşletme Fakültesi Uluslararası Ticaret Bölümü'nde öğrenim görmüş mezunlar ve hâli hazırda öğrenimine devam eden öğrenciler oluşturmaktadır. Araştırmanın örneklemini ise 2014-2015, 2015-2016, 2016-2017, 2017-2018 öğrenim yıllarının güz ve bahar dönemlerinde; 2018-2019 öğrenim yılının ise güz döneminde derslere kayıtlı olan öğrenciler oluşturmaktadır. Bölümde sekizinci yarıyılda tam zamanlı zorunlu işyeri uygulaması bulunuyor olması nedeniyle bu dönemde öğrenciler ders almadıkları için örneklemde sekizinci yarıyıl değerlendirmesi bulunmamaktadır.

SAÜ Uluslararası Ticaret Bölümü ilk kez 2013-2014 yılı güz döneminde öğrenci kaydı alarak aktif olarak öğretime başlamış bir bölümdür. 2014-2015 güz dönemi sonunda ise Bölüm Başkanlığı kararı ile öğretim elamanlarının değerlendirilmesi amacıyla ulaşılabilen tüm lisans öğrencilerine anket uygulaması yapılmaktadır. Anketler, dönem sonu itibariyle öğrencilerin herhangi bir baskı altında olmadan cevap verebilmeleri açısından isimleri sorulmaksızın, bıraktopla yöntemi ile uygulanmaktadır. On beş maddeden oluşan bu anket formu, North West Üniversitesi tarafindan uygulanan, geçerliliği ve güvenilirliği Montshiwa ve Moroke (2014) tarafindan test edilen Öğrenci-Öğretim Üyesi Değerlendirme anketinden faydalanılarak oluşturulmuş bir anket formudur. Ancak bu form oluşturulurken öğretim üyesi ile ilgili ve memnuniyete ilişkin sorular seçilmiştir. Beşli Likert Ölçeği ile yöneltilen bu sorulara ek olarak öğrencilere dersin öğretim üyesine yönelik memnuniyetini sorgulayan bir soru yöneltilmektedir.

$\mathrm{Bu}$ çalışmadaki anket uygulamasının isimsiz yapılması mecburiyeti nedeniyle ders tekrarı yapan öğrencilerin mükerrer ders değerlendirmeleri söz konusudur. Bu durum araştırmada bir kısıt olarak değerlendirilmektedir. İlgili kısıt nedeniyle anket katılımcılarının sayısı net olmasa da yaklaşık olarak 250 öğrencinin araştırmanın örneklemini oluşturduğu düşünülmektedir.

Katılımcı öğrenciler tarafindan kayıtlı oldukları dönemlerin sonlarında aldıkları beş ders değerlendirmesi yapılmış, toplamda 41 farklı dersin öğretim üyesi değerlendirilmiş ve 5.423 ders değerlendirme gözlemine ulaşılmıştır. Analize dâhil edilen bu gözlemler, araştırma evrenini temsil etme kabiliyetine sahiptir. Gözlemlerin öğrenim yılları ve sınıflar düzeyindeki dağılımları Tablo 1'de incelenebilir. 
Tablo 1. Araştırma Örnekleminin Yıllar ve Sınıflar Bazında Dağılımları

\begin{tabular}{|c|c|c|c|c|c|c|c|}
\hline & \multicolumn{5}{|c|}{ ÖĞRENİM YILI* } & \multirow[b]{2}{*}{ Toplam } \\
\hline & & 2014-2015 & 2015-2016 & 2016-2017 & $2017-2018$ & 2018-2019 & \\
\hline \multirow{7}{*}{ Yariyıl } & 1 & 115 & 150 & 270 & 265 & 245 & 1045 \\
\hline & 2 & 145 & 160 & 330 & 385 & - & 1020 \\
\hline & 3 & 110 & 150 & 115 & 295 & 245 & 915 \\
\hline & 4 & 130 & 105 & 215 & 290 & - & 740 \\
\hline & 5 & 0 & 130 & 95 & 200 & 304 & 729 \\
\hline & 6 & 0 & 100 & 140 & 280 & - & 520 \\
\hline & 7 & 0 & 0 & 64 & 155 & 235 & 454 \\
\hline \multicolumn{2}{|c|}{ Toplam } & 500 & 795 & 1229 & 1870 & 1029 & 5423 \\
\hline
\end{tabular}

*Renklendirilmiş dönemler Bölüm 4.3'te analizi yapılan sınıfları göstermektedir.

Anketler aracılığı ile toplanan veriler, nicel yöntemlerden "Temel Bileşenler Faktör Analizi” ve "Lineer Çoklu Regresyon" teknikleri ile analiz edilerek bulgular sunulmaktadır.

\section{Bulgular}

Bu bölümde öncelikle kullanılan ölçeğin boyutları belirlenmekte ve çalışmanın güvenilirliği tespit edilmekte; sonrasında ise öğretim üyesine yönelik memnuniyeti açıklayan faktörler incelenmekte ve sonuçların geçerliliği test edilmektedir.

\section{Kullanılan Ölçeğin Boyutları}

Öncelikle verilerin tutarlılığının ölçülmesi amacıyla Kaiser-Meyer-Olkin (KMO) ölçütü kullanılmaktadır. KMO, faktör analizinin uygunluğunu gösteren bir indistir. KMO değeri olarak 0,5-1,0 arası değerler kabul edilebilir olarak değerlendirilirken 0,5 'in altındaki değerler faktör analizinin söz konusu veri seti için uygun olmadığının göstergesidir. Genel olarak araştırmacılarca tatminkâr olarak düşünülen KMO değeri 0,7'dir (Altunışık vd., 2012). Araştırmanın veri setinin KMO değeri 0,948 olup verilerin tutarlı olduğu görülmektedir.

Kullanılan ölçeğin boyutlarının tespit edilmesi amacıyla "Temel Bileşenler Faktör Analizi" yapılmaktadır. Ortagonal (Varimaks) döndürme neticesinde elde edilen sonuçlar Tablo 2'de sunulmaktadir.

Tablo 2. Faktör Analizi Sonuçları

\begin{tabular}{|c|c|c|c|}
\hline Faktör 1 - Öğretme Performansı & $\begin{array}{l}\text { Faktör } \\
\text { Yükleri }\end{array}$ & $\begin{array}{l}\text { Açıklanan } \\
\text { Varyans\% }\end{array}$ & $\begin{array}{l}\text { Cron- } \\
\text { bach } \alpha\end{array}$ \\
\hline Derste ilgiyi sürekli canlı tutar, derste sıkılmam. & ,755 & \multirow{10}{*}{48,47} & \multirow{10}{*}{0,896} \\
\hline Sorulan sorulara açık, net ve tatminkâr cevaplar verir. & ,755 & & \\
\hline Bu dersin konuları iyi seçilmiştir. & ,745 & & \\
\hline Derse hazır gelir. & ,732 & & \\
\hline Alanındaki güncel değişimleri takip eder. & ,653 & & \\
\hline Bizlerin derse katılımını sağlar. & 638 & & \\
\hline Derse ilişkin verdiği/tavsiye ettiği kaynaklar yeterlidir. & 636 & & \\
\hline Bilgi düzeyi bu dersi anlatmak için bence yeterlidir. & ,588 & & \\
\hline Derse ilişkin ödevlerin bana faydası olduğuna inanıyorum. & ,543 & & \\
\hline Ders saatleri dışında da ulaşmak ve görüşmek mümkündür. & ,523 & & \\
\hline
\end{tabular}




\begin{tabular}{|l|c|c|c|}
\hline Faktör 2 - Ölçme ve Değerlendirme & & & \\
\hline Öğrencilerin hepsine eşit uzaklıktadır. &, 845 & & \multirow{2}{*}{0,783} \\
\hline Sınavların adil değerlendirildiğine inanıyorum. &, 810 & \multirow{2}{*}{7,65} &, 576 \\
\cline { 1 - 2 } Sınıfta rahat ve dostça bir ortam oluşturur. &, 545 & & \\
\hline Sınav soruları derste öğrendiklerimizi sorgulamaktadır. & & \\
\hline
\end{tabular}

Montshiwa ve Moroke (2014) tarafindan test edilen Öğrenci-Öğretim Üyesi Değerlendirme anketinin orijinalinde 26 madde bulunmakta ve bu boyutlar "hazırlık, sunum ve değerlendirme; öğrencilerle ilişkiler; öğrencileri cesaretlendirme ve motive etme ile ders içeriğinin farkındalığı" olmak üzere dört boyutta toplanmaktadır. Araştırmada kullanılan on dört maddeden oluşan ölçeğin; yapılan sadeleştirmelerin bir sonucu olarak iki boyuttan oluştuğu görülmektedir. $\mathrm{Bu}$ boyutların öğretme performansı ile ölçme ve değerlendirme şeklinde adlandırılması uygun bulunmaktadır. Bu iki boyut ile açıklanan toplam varyansın \%56,4 olduğu görülmektedir. Boyutların güvenilirliği Cronbach Alpha ile ölçülmekte ve elde edilen değerlerin yeterli olduğu sonucuna ulaşılmaktadır (Tablo 2).

\section{Öğretim Üyesine Yönelik Memnuniyeti Belirleyen Faktörler}

Öğretim üyesinden duyulan memnuniyetin hangi faktörlerce belirlendiğini tespit edebilmek adına tüm örneklem üzerinde "Kademeli Lineer Çoklu Regresyon Analizi" yapılmaktadır. Denenen on modelden sonuncusu optimum model olup bu model \%62,9 oranında açıklayıcılığa sahiptir. Ancak önerilen modellerden altıncı modelden sonrasında eklenen diğer değişkenlerin açıklayıcılığı büyük oranda değiştirmediği gözlemlendiğinden, sonuçları yorumlamayı kolaylaştırmak adına altıncı model benimsenerek, bu modelin değişkenleri üzerinde durulmaktadır. Tablo 3'te görüleceği üzere model 6'nın düzeltilmiş R2 'si \%62,5 olup Anova sonuçları da modelin anlamlı olduğunu göstermektedir $(F=1342 ; p<0,001)$.

Tablo 3. Kademeli Çoklu Regresyon Analizi -Model Önerileri

\begin{tabular}{|c|c|c|c|c|}
\hline Model & $\mathbf{R}$ & $\mathbf{R}^{\mathbf{2}}$ & Düzeltilmiş $\mathbf{R}^{\mathbf{2}}$ & $\begin{array}{c}\text { Tahminin } \\
\text { Standart Hatası }\end{array}$ \\
\hline 1 &, $651^{\mathrm{a}}$ &, 424 &, 424 &, 93661 \\
\hline 2 &, $726^{\mathrm{b}}$ &, 527 &, 526 &, 84903 \\
\hline 3 &, $755^{\mathrm{c}}$ &, 571 &, 570 &, 80872 \\
\hline 4 &, $774^{\mathrm{d}}$ &, 599 &, 598 &, 78183 \\
\hline 5 &, $784^{\mathrm{e}}$ &, 615 &, 615 &, 76588 \\
\hline 6 &, $791^{\mathrm{f}}$ &, 625 &, 625 &, 75575 \\
\hline 7 &, $793^{\mathrm{g}}$ &, 628 &, 628 &, 75285 \\
\hline 8 &, $793^{\mathrm{h}}$ &, 629 &, 629 &, 75189 \\
\hline 9 &, $793^{\mathrm{i}}$ &, 630 &, 629 &, 75160 \\
\hline 10 &, $794^{\mathrm{j}}$ &, 630 &, 629 &, 75138 \\
\hline
\end{tabular}

Tablo 4'te ise Model 6'nın değişkenleri ve bu değişkenlerin bağımlı değişken olan öğretim üyesine yönelik memnuniyet ile etkileşimlerinin yönü ve şiddeti özetlenmektedir. 
Tablo 4. Tüm Örneklem Üzerinde Yapılan Regresyon Analizinde Değişken Katsayıları

\begin{tabular}{|l|c|c|c|c|c|}
\hline & B & $\begin{array}{c}\text { Standart } \\
\text { Hata }\end{array}$ & Beta & t & Anlamlılı* \\
\hline Sabit &,- 525 &, 059 & & $-8,871$ &, 001 \\
\hline Derste ilgiyi sürekli canlı tutar, derste sıkılmam. &, 194 &, 012 &, 212 & 16,653 &, 001 \\
\hline Sorulan sorulara açık, net ve tatminkâr cevaplar verir. &, 180 &, 015 &, 159 & 11,673 &, 001 \\
\hline Sinıfta rahat ve dostça bir ortam oluşturur. &, 194 &, 012 &, 191 & 16,067 &, 001 \\
\hline Bu dersin konuları iyi seçilmiştir. &, 151 &, 012 &, 148 & 13,041 &, 001 \\
\hline Derse hazır gelir. &, 168 &, 016 &, 133 & 10,548 &, 001 \\
\hline Sinav soruları derste öğrendiklerimizi sorgulamaktadır. &, 107 &, 013 &, 096 & 8,264 &, 001 \\
\hline
\end{tabular}

* 0.001'den küçük değerler yuvarlama nedeniyle 0.001 olarak belirtilmiştir.

Elde edilen analiz sonuçlarına göre öğrencilerin, öğretim elemanları ile etkileşimlerinin ve iletişimlerinin memnuniyetin temel belirleyicisi olduğu görülmektedir. $\mathrm{Bu}$ değerlendirmelerin ardından ders içeriği ve öğretim üyesinin ders öncesi hazırlıklarına işaret eden maddeler gelmektedir. Son olarak da ölçme ve değerlendirme ile ilgili bir madde bu siralamayı takip etmektedir.

\section{Ölçek Geçerliliğinin Test Edilmesi}

Dışsal geçerliliğinin ölçülmesi amacıyla tüm dönemlerdeki değerlendirmelere katılan iki grup, daha açık bir şekilde ifade etmek gerekirse:

- 2014-2015 öğretim yılında birinci yarıyılda öğrenimine başlayarak 2017-2018 öğrenim y1lında yedinci yarıyılını tamamlayan sinif (A sinifi) ile

- 2015-2016 da birinci yarıyılında öğrenimine başlayarak 2018-2019 öğrenim yılında yedinci yarıyılını bitiren sinıf (B sinıfı),

farklı iki örneklem olarak belirlenip regresyon analizleri bu örneklemler üzerinde tekrar edilerek karşılaştırılmaktadır. Bu örneklemlerde alınan dersler ve alınan dersleri veren öğretim elamanları bazı istisnalar dışında aynıdır. Dolayısıyla her iki sınıf üzerinde gerçekleştirilen analizlerin sonuçlarının farklılaşmasının başlıca nedeninin sınıf büyüklüğü ve akran psikolojisi olabileceği öngörülmektedir. Analiz sonuçları Tablo 5'te aktarılmaktadır.

Tablo 5. Regresyon Analizi Değişken Katsayıları Karşılaştırma Tablosu

\begin{tabular}{|l|c|c|c|}
\hline & A Sınıfı & B Sınıfı & $\begin{array}{c}\text { Tüm } \\
\text { Ornneklem }\end{array}$ \\
\hline Derse hazır gelir. &, 222 &, 175 &, 133 \\
\hline Bu dersin konuları iyi seçilmiştir. &, 133 &, 196 &, 148 \\
\hline Derste ilgiyi sürekli canlı tutar, derste sıkılmam. &, 158 &, 239 &, 212 \\
\hline Sınıfta rahat ve dostça bir ortam oluşturur. &, 196 &, 259 &, 191 \\
\hline Ders saatleri dışında da ulaşmak ve görüşmek mümkündür. & &, 088 & \\
\hline Derse ilişkin ödevlerin bana faydası olduğuna inanıyorum. & &, 099 & \\
\hline Derse ilişkin verdiği/tavsiye ettiği kaynaklar yeterlidir. &, 137 & & \\
\hline Sorulan sorulara açık, net ve tatminkâr cevaplar verir. &, 183 & &, 159 \\
\hline Sınav soruları derste öğrendiklerimizi sorgulamaktadır. & & &, 096 \\
\hline DÜZELTíLMiş R $\mathbf{R}^{2}$ & $\mathbf{0 , 6 5 8}$ & $\mathbf{0 , 6 8 1}$ & $\mathbf{0 , 6 2 5}$ \\
\hline
\end{tabular}


Her üç regresyon analizinde de Düzeltilmiş R2 değerleri birbirine yakındır. Bununla birlikte düzeltilmiş R2 üzerindeki etkisi 0,005 'ten düşük olan değişkenler modellerden dışlandığında kalan değişkenlerden dördünün her üç örneklemde de ortak olduğu görülmektedir. Bu bulgular ölçeğin dışsal olarak da geçerli sayılabileceğine işaret etmektedir. Diğer yandan her bir örneklemin, diğerlerinde bulunmayan iki farklı değişken içerdiği görülmektedir.

Farklılaşan değişkenlerden ikisi iletişimle ilgilidir. Bununla birlikte, A sınıfı sorulan sorulara aldıkları cevaplarla ilgili iletişim kalitesine vurgu yaparken; B sınıfı ders dışında erişebilirlik konusuna önem vermektedir. A sınıfının mevcudu yaklaşık olarak B sınıfının mevcudunun yarısıdır. O nedenle A sınıfının sorularına sınıf içinde cevap alabildikleri; B sınıfının ise sınıfın kalabalık olması nedeniyle öğretim elemanlarına sınıf içerisinde ulaşmaktansa; sorularına sınıf dışında ulaşarak cevap aradığı şeklinde yorumlanabilir.

Farkl1laşan diğer değişkenlerin faktör yüklerinin diğer değişkenlere görece az olması nedeniyle göz ardı edilebileceği düşünülmektedir. Sonuç olarak, sınıf büyüklüğünün öğretim üyelerine yönelik memnuniyeti belirleyen kriterler açısından etkisinin göz ardı edilebileceği sonucuna ulaşılmaktadır.

\section{Sınıf Düzeyinde Öğretim Üyesine Yönelik Memnuniyeti Etkileyen Faktörler}

Öğretim elemanlarına yönelik memnuniyeti etkileyen faktörlerin sınıf düzeyine göre farklılaşıp farklılaşmadığını görmek adına örneklem sınıf düzeyinde ayrıştırılarak dört farklı regresyon analizi gerçekleştirilmektedir. $\mathrm{Bu}$ analizlerin bulguları hem anket sonuçlarını değerlendirme anlamında hem de öğrenci beklentilerini öngörebilmek anlamında yazına katkıda bulunacaktır. Clayson (2018)'un da belirttiği üzere sınıf karşılaştırmaları yapılarak anket sonuçlarının yorumlanması araştırmanın güvenilirliği konusunda da fikir verebilmektedir. Bu doğrultuda gerçekleştirilen analizler sonucu elde edilen sonuçlar Tablo 6' da özetlenmektedir.

Tablo 6. Sınıf Düzeyinde Regresyon Analizleri Değişken Katsayıları Özet Tablosu

\begin{tabular}{|l|c|c|c|c|}
\hline & $\begin{array}{c}\mathbf{1 .} \text { ve 2. } \\
\text { Yarıyıl }\end{array}$ & $\begin{array}{c}\text { 3. ve 4. } \\
\text { Yarıyıl }\end{array}$ & $\begin{array}{c}\mathbf{5 .} \text { ve 6. } \\
\text { Yarıyıl }\end{array}$ & $\begin{array}{c}\mathbf{7 .} \\
\text { Yarıyıl }\end{array}$ \\
\hline Derse hazır gelir. &, 208 &, 127 &, 194 &, 180 \\
\hline Bu dersin konuları iyi seçilmiştir. &, 135 &, 189 &, 134 &, 212 \\
\hline Derste ilgiyi sürekli canlı tutar, derste sıkılmam. &, 198 &, 130 &, 305 &, 220 \\
\hline Sınıfta rahat ve dostça bir ortam oluşturur. &, 192 &, 294 &, 198 &, 238 \\
\hline Derse ilişkin ödevlerin bana faydası olduğuna inanıyorum. &, 109 & &, 139 &, 117 \\
\hline Sorulan sorulara açık, net ve tatminkâr cevaplar verir. &, 165 &, 172 & & \\
\hline Ders saatleri dişında da ulaşmak ve görüşmek mümkündür. & & & &, 146 \\
\hline Sınav soruları derste öğrendiklerimizi sorgulamaktadır. & & &, 107 & \\
\hline Derse ilişkin verdiği/tavsiye ettiği kaynaklar yeterlidir. & &, 159 & & \\
\hline DÜZELTíLMiş R $\mathbf{R}^{\mathbf{2}}$ & $\mathbf{0 , 6 9 3}$ & $\mathbf{0 , 6 6 0}$ & $\mathbf{0 , 6 7 8}$ & $\mathbf{0 , 6 6 8}$ \\
\hline
\end{tabular}

Tablo 6 incelendiğinde, her sınıf seviyesinde açıklanan varyansın oldukça yakın seviyelerde olduğu görülmektedir. Öğretim üyesine yönelik memnuniyeti belirleyen faktörlerin altısının dördü her sınıfta aynıdır. Bu faktörler aynı zamanda tek bir istisna dışında her modelde açıklayıcılığı en yüksek olan faktörlerdir. Dolayısıyla bu sonuçlar araştırmanın geçerliliğini desteklemektedir. 
Sınıf düzeyinde farklılaşan faktörler incelendiğinde ise birinci ve ikinci sinıflarda "Sorulan sorulara açık, net ve tatminkâr cevap verir." maddesinin işaret ettiği iletişim beklentisi faktörünün yerini dördüncü sınıflarda yine aynı faktöre işaret eden "ders saatleri dışında da ulaşmak ve görüşmek mümkündür.” maddesinin aldığı görülmektedir. Üçüncü sınıftaki öğrencilerde ise bu faktörün etkili olmadığı görülmektedir. Bu durum üniversite öğrenimine yeni başladığı için eğitim-öğretim süreçleri hakkında bilgi edinme ihtiyacında olan ilk sınıfların ve de işyeri eğitimi, bitirme çalışması gibi yeni tecrübeler edinmek üzere olan ve sınıf dış1 aktivitelerin yoğunluğunun fazla olduğu son sınıfta, öğretim elamanlarıyla sağlıklı iletişim beklentilerinin daha yüksek olduğu şeklinde yorumlanabilir. Birinci sınıf öğrencilerinin derslerle ilgili süreçler konusunda bilgi ihtiyacı olduğu; son sınıfların ise işyeri eğitimi ve bitirme çalışması gibi ders dışı öğrenim aktiviteleri konusunda bilgi ihtiyacının bulunuyor olması nedeniyle; ilkinde soru-cevap; ikincisi ise ders dışı ulaşılabilirlik faktörleri önem arz etmektedir.

Öğrencilerin ders değerlendirmelerinde, belirli bir derste herhangi bir konuda yaşadıkları bir problem nedeniyle ilgili faktörün algıda seçicilikten ötürü daha etkili bir şekilde cevaplara yansıması da faktörler arasındaki farklılığı açıklayabilecek bir diğer önerme olabilir. Bu durum da tavsiye edilen kaynakların yeterliliği ve sınav sorularının derste öğretilenlerden sorulup sorulmaması ile ilgili farklılaşmayı açıklayabilecek bir durum olarak göz önünde bulundurulmalıdır.

\section{Sonuç}

Öğretim süreçlerinin iyileştirilmesi ya da öğretim elemanlarının öğretim performanslarının değerlendirilebilmesi açısından ders değerlendirme anketleri, kabul gören ölçme araçları olarak görülmektedir. Bununla beraber, yazında anket uygulamalarının hangi bölümlerde uygulandı̆̆ uygulanan sınıfların büyüklüğ̈̈, öğretim üyelerinin cinsiyetleri gibi öğretim elemanının performansı ile doğrudan ilişkili olmayan bazı faktörlerin bu değerlendirmelerde sapmalara yol açabileceğine dair bulgular bulunmaktadır.

$\mathrm{Bu}$ araştırmada dört yıl boyunca aynı öğretim üyeleri tarafından aynı bölümde okuyan öğrencilere uygulanan anket formları değerlendirilerek sınıf farklılıklarının öğretim üyesine yönelik memnuniyet değerlendirmelerini etkileyip etkilemediği değerlendirilmektedir. Öğretim üyelerinin istisnalar dışında aynı olması, öğrencilerin aynı bölümde okuyan öğrenciler olması, dört yıl boyunca alınan tüm derslerin değerlendirilmesi, değerlendirmeler üzerindeki sapmalara neden olan pek çok değişkenin sabitlenmiş olduğu şeklinde yorumlanmalıdır. Sonuç olarak değerlendirmelerdeki farklılıkların açıklaması olarak sınıf farklılıklarına odaklanmak mümkün olabilmektedir. Nitekim, yazında bunun dışında sapmaya neden olabilecek başka bir faktöre rastlanmamıştır.

Yapılan analizler sonucu yedi dönem boyunca aldığı tüm dersleri değerlendiren iki farklı sınıfın öğretim üyelerine yönelik memnuniyetini belirleyen faktörlerin dört tanesinin ortak olduğu, ikisinin farklılaştığ görülmüştür. Ancak tespit edilen bu farklılıklarda sınıf büyüklüğünün etkisinin yüksek olduğu şeklinde bir yargıya varılmasının doğru olmadığ kanısına varılmıştır. Bu nedenle öncelikle kullanılan ölçeğin geçerli olduğu, ikinci olarak da sınıf büyüklüğünün etkisinin göz ardı edilebilir olduğu sonucuna ulaşılmaktadır. 
Çalışmanın devamında ise farklı seviyelerdeki sınıflara devam eden öğrencilerin öğretim üyelerine yönelik memnuniyetini etkileyen faktörleri etkileyip etkilemediği araştırılmıştır. Birinci, ikinci, üçüncü ve dördüncü sınıflara devam eden öğrencilerin memnuniyetini etkileyen faktörler bazı istisnalar dışında aynıdır. Ancak farklılaşan faktörlerin açıklamalarının oldukça yorumlanabilir nitelikte olduğu görülmektedir. Birinci sınıf öğrencilerinin derslerle ilgili süreçler konusunda; son sınıfların ise işyeri eğitimi ve bitirme çalışması gibi ders dışı öğrenim aktiviteleri konusunda bilgi ihtiyaçlarının bulunuyor olması nedeniyle; ilkinde soru-cevap; ikincisi ise ders dışı ulaşılabilirlik faktörleri önem arz etmektedir. Buna ek olarak genel işletme derslerinin alındığ 1 birinci sınıftan sonra alana özgü derslerin başladığı ikinci sınıfta öğretim elemanları tarafindan sağlanan kaynakların memnuniyet üzerindeki etkisinin arttı̆̆ görülmektedir.

Araştırma sonuçlarından yola çıkarak öğretim üyelerinin sınıf düzeylerine göre beklentilerin değiştiğini gözeterek öğretim faaliyetlerine devam etmelerinin öğretim üyesine yönelik memnuniyeti de arttırabileceği görülmektedir.

\section{Kaynakça}

Açan, B. ve Saydan, R. (2009). Öğretim elemanlarının akademik kalite özelliklerinin değerlendirilmesi: Kafkas Üniversitesi İIBF örneği. Atatürk Üniversitesi Sosyal Bilimler Enstitüsü Dergisi, 13(2), 225253.

Ahmadi, M., Helms, M. M. \& Raiszadeh, F. (2001). Business students' perceptions of faculty evaluations. International Journal of Educational Management, 15(1), 12-22.

Aigner, D. J. \& Thum, F. D. (1986). On student evaluation of teaching ability. The Journal of Economic Education, 17(4), 243-265.

Alemoni, L. M. \& Hexner, P. Z. (1980). A review of theresearch on student evaluation anda report on the effect of different sets of instructions on student course and instructor evaluation. Instructional Science, 9, 67-84.

Altunışık, R., Coşkun, R., Bayraktaroğlu, S. ve Yıldırım, E. (2012). Sosyal bilimlerde araştırma yöntemleri SPSS uygulamall (7. Baskı). Sakarya: Sakarya Kitabevi.

Arcidiacono, P. \& Nicholson, S. (2005). Peer effects in medical school. Journal of Public Economics, 89, $327-350$.

Başkır, M. B., Yıldırım, G. ve Yıldırım, F. (2015, Kasım). Improving evaluation system of program educational objectives and outcomes based on mudek criteriausing fuzzy approach. Paper presented at the 4th International Fuzzy Systems Symposium, İstanbul, Türkiye.

Başkır, M. B., Küçükönder, H., Çelik, N. ve Güzel, M. S. (2017). Öğretim kalitesi değerlendirmesine yeni bir yaklaşım: Bartın üniversitesi örneği. Bartın Üniversitesi Eğitim Fakültesi Dergisi, 6(2), 468-485.

Cashin, W. E. (1995). Student ratings of teaching: The research revisited. IDEA PAPER, 32.

Chen, Y. \& Hoshower, L. B. (2003). Student evaluation of teaching effectiveness: An assessment of student perception and motivation. Assessment \& Evaluation in Higher Education, 28(1), 71-88.

Clayson, D. E. (2018). Student evaluation of teaching and matters of reliability. Assesment \& Evaluation in Higher Education, 43(4), 666-681. 
Cohen, P. A. (1981). Student ratings of instruction and student achievement: A meta-analysis of multisection validity studies. Review of Educational Research, 51, 281--309.

Devebakan, N., Koçder, H., Musal, B. ve Güner, G. (2003). Dokuz Eylül Üniversitesi Sağlık Bilimler Enstitüsünde lisansüstü eğitim kalitesinin arttırılması kapsamında öğrencilerin eğitime ilişkin görüşlerinin değerlendirilmesi. Dokuz Eylül Üniversitesi Sosyal Bilimler Enstitüsü Dergisi, 5(2), 3044.

Dunrong, B. \& Fan M. (2009). On student evaluation of teaching and improvement of the teaching quality assurance system at higher education institutions. Chinese Education \& Society, 42(2), 100115.

Esen, M. ve Esen, D. (2015). Öğretim üyelerinin performans değerlendirme sistemine yönelik tutumlarının araştırılması. Yükseköğretim ve Bilim Dergisi, 5(1), 52-67.

Forsyth, D. R. (2014). The Psychology of Groups. Psychology içinde editörler R.B. Diener ve E. Diener. Noba Textbook Series. Champaign, IL: DEF Publishers. [Çevrim-içi: http://nobaproject.com/textbooks/introduction-to-psychology-the-full-noba-collection], Erişim Tarihi:25.01.2019.

Greenwald, A. G. (1997). Validity concerns and usefulness of student ratings of instruction. American Psychologist, November, 1182-1186.

Hajdin, G. \& Pazur, K. (2012). Differentiating between student evaluation of teacher and teaching effectiveness. Journal of information and organizational sciences, 36(2), 123-134.

Hanushek, E. A., Kain, J. F., Markman J. M. \& Rivkin, S. G. (2003). Does peer ability affect student achievement? Journal of Applied Econometrics, 18, 527-544.

Heine, P. \& Maddox, N. (2009). Student perceptions of the faculty course evaluation process: An exploratory study of gender and class differences. Research In Higher Education Journal, 3.

Hobson, S. M. \& Talbot, D. M. (2001). Understanding student evaluations: what all faculty should know. College Teaching, 49(1), 26-31.

Hoxby, C. (2001). Peer effects in the classroom: learning from gender and race variation. NBER Working Paper Series, WP7867.

Kaschak, E. (1978). Sex bias in student evaluations of college professors. Psychology of Women Quarterly, 2(3), 235-242.

Kember, D. \& Wong, A. (2000). Implications for evaluation from a study of students' perceptions of good and poor teaching. Higher Education, 40, 69-97.

Kim, H., Cagle, M. N. ve Çakar, U. (2016). Evaluating the instructor effectiveness: A Turkish business faculty example. Dokuz Eylül Üniversitesi Işletme Fakültesi Dergisi, 17(1), 65-87.

Kulik, J. A. (2001). Student ratings: validity, utility, and controversy. New Directions and Institutional Research, 109, 9-25.

Kwan, K. P. (1999). How fair are student ratings in assessing the teaching performance of university teachers? Assesment \& Evaluation in Higher Educatio, 24(2), 181-195.

Marsh, H. W. (1984). Students' evaluations of university teaching: Dimensionality, reliability, validity, potential biases, and utility. Journal of Educational Psychology, 76, 707--754. 
Marsh, H. W. (1987). Students' evaluations of university teaching: research findings, methodological issues, and directions for future research. International Journal of Educational Research, 11, 253388.

Martins, P. \& Walker, I. (2006). Student achievement and university classes: effects of attendence, size, peers, and teachers, IZA Discussion Paper Series, 2490.

McKeachie, W. J. (1990). Research on college teaching: The historical background. Journal of Educational Psychology, 82, 189-200.

Monks, J. \& Schmidt, R. (2010). The impact of class size and number of students on outcomes in higher education. Cornell University Working Paper Series, WP136.

Montshiwa, V. T. \& Moroke, N. D. (2014). Assessment of the reliability and validity of student-lecturer evaluation questionnaire: A case of North West University. Mediterranean Journal of Social Sciences, 5(14), 352-364.

Neath, I. (1996). How to improve your teaching evaluations without improving your teaching. Psychological Reports, 78, 1363-1372.

Noyan, F. ve Yıldız, D. (2006). YTÜ’de öğrenci gözüyle öğretim üyesi etkinliğinin iki aşamalı modeller yardımı ile değerlendirilmesi. Mühendislik ve Fen Bilimleri Dergisi, 2006/1, 34-45.

Pamuk, M. (2005). Öğrencilerin öğretim üyesini değerlendirmesine ait bir uygulama. Ekonometri ve Istatistik, 1, 41-49.

Patır, S. (2009). Faktör analizi ile öğretim üyesi değerleme çalışması. Atatürk Üniversitesi İktisadi ve Idari Bilimler Dergisi, 23(4), 69-86.

Pedder, D. (2006). Are small classes better? Understanding relationships between class size, classroom processes and pupils' learning. Oxford Review of Education, 32(2), 213-234.

Pounder, J. S. (2007). Is student evaluation of teaching worthwhile?: An analytical framework for answering question. Quality Assurance in Education, 15(2), 178-191.

Radmacher, S. A. \& Martin, D. J. (2001). Identifying significant predictors of student evaluations of faculty through hierarchical regression analysis. The Journal ofPsychology: Interdisciplinary and Applied, 135(3), 259-268.

Seldin, P. (1993). The use and abuse of student ratings of professors. The Chronicle of Higher Education, 39(46), A40.

Shevlin, M., Banyard, P., Davies, M. \& Griffiths, M. (2000). The validity of student evaluation of teaching in higher education: Love me, love my lecturers? Assessment \& Evaluation in Higher Education, 25(4), 397-405.

Siegfried, J. \& Kennedy, P. (1995). Does pedagogy vary with class size in introductory economics? American Economic Review, 85(2), 347-352.

Sinclair, L. \& Kunda, Z. (2000). Motivated stereotyping of women: she's fine if she praised me but incompetent if she criticized me. Personality and Social Psychology Bulletin, 25(11), 1329-1342.

Thng, Y. X. (2017). The effects of class size on student behavioral outcomes: the role of teacher-student interactions (Doctoral dissertation). Harvard Graduate School of Education Database. 
Tonbul, Y. (2008). Öğretim elamanlarının performansının değerlendirilmesine ilişkin öğretim üyesi ve öğrenci görüşleri. Kuram ve Uygulamada Ĕ̆itim Yönetimi, 56, 633-662.

Wachtel, H. K. (1998). Student evaluation of college teaching effectiveness: a brief review. Assesment \& Evaluation in Higher Education, 23(2), 191-212.

Yurtkoru, E. S. ve Sipahi, B. (2003). Öğretim üyesi performans değerlendirme kriterinin cinsiyete göre belirlenmesi üzerine analitik bir çalışma. Istanbul Ticaret Üniversitesi Fen Bilimleri Dergisi, 2(4), 13-37.

Zabaleta, F. (2007). The use and misuse of student evaluations of teaching. Teaching in Higher Education, 12(1), 55-76. 


\section{Extended Abstract}

\section{Introduction}

In higher education, the evaluation of the instructors by students via questionnaires has become a common practice over the years. These evaluations are used as inputs in decisions related to quality improvement in education. Because of this high mission of these evaluations, the validity of the practice is also questioned in related literature. Some researchers suggest that these questionnaires may give deviant results by the effect of some factors other than the performance of the instructor. These factors can be classified as factors related to the course taken, factors related to the instructor but not related to his/her instructional performance and factors related to class differences.

The aim of this study is to examine whether class differences have an impact on the satisfaction with instructors. The results may provide advices to instructors in increasing the satisfaction of the students who attend different classes.

\section{Method}

The dataset of the study consists of questionnaire data which are applied on the students who had taken courses in all periods from 2014 fall term until the end of 2018 at International Trade Department of Sakarya University Business School. Hence the dataset of the research is evaluated as longitudinal data. In the end of each semester authorized instructor who is not the lecturer of the course holds the questionnaires so students can give answers in a confidential environment. Also, no any personal information such as sex or name is required.

Thanks to the longitudinal dataset, class differences can be handled in two ways. Firstly, in this data there are two group of students who belong to two different classes and who attended to all the courses of the program one year apart (Class A and Class B). The factors which are related to the satisfaction with instructors are analyzed by Multi-Criteria Linear Regression Analysis for these two classes by one by and then compared and discussed.

Secondly, the class levels are taken into account (namely first, second, third and fourth year students). Whether the factors related to the satisfaction with instructors change during the education period, is discussed because the study contains the view of same students in different semesters.

\section{Results}

The results of Multi-Criteria Linear Regression Analysis conducted on Class A and Class $\mathrm{B}$ show that the explained variances are similar (65\% and 68\% respectively). In addition to this, the variables which are related to the satisfaction with instructors are also similar, except for two variables. While students of Class A put emphasis on clear and satisfactory answers to their questions, the students of Class B notice the availability of instructors out of class. Both of these expectations are related to communication and interaction. The number of students attended Class B is nearly twice of the number of students who attend Class A. So that, it can be presumed that in a crowded class, students tend to get answers to their questions out of the class. On the other hand, students in uncrowded classes tend to ask their questions in class. Despite this difference and some other, it is concluded that the differences regarding the factors determining the satisfaction of these two classes can be ignored in this case. 
When the factors which are related to the satisfaction with instructors are compared among students attending different level of classes, it is seen that some obvious differences show up. First and second year students who need lots of information related to higher education processes demand clear and satisfactory explanations from instructors. These expectations seem to abolish in the following years. However, in the last year of education, expectations related to communication gain importance again in a different way. Probably, due to the need for information on extracurricular learning activities such as workplace training and graduation project; fourth year students need face-to-face communication out of class. So that, it is possible to propose that the expectations of the students regarding instructors change during their four-year education. That is, the expectations and necessities of students are changed by years.

\section{Discussion}

In this study, longitudinal data related to satisfaction with instructors are examined in order to see the effect of class differences. Therefore, paper contains the view of students by observing at different times contrary to cross sectional studies. However, the results are valid for only the sample and chosen semesters in this study. Replication of the methodology in other departments will provide more insights about generalizability of the results. 